\title{
Refining Decisions for Identifying Primary Care Patients Who Require A Work-Up for Glaucoma: Intraocular Pressure Changes with Central Corneal Thickness
}

*Ronald Gall, OD MSc

Private Practice

506 Kerr Street

Oakville, ON, L6K 3C5, Canada

ron@visionsource-drgall.com

\author{
Bruce Wick, OD PhD \\ Professor Emeritus \\ University of Houston College of \\ Optometry \\ Houston, TX
}

(*corresponding author)

\begin{abstract}
PURPOSE

The factors associated with the increased risk of glaucoma include intraocular pressure (IOP), central corneal thickness (CCT), vertical cup-to-disc ratio, visual field index, age, and diabetes mellitus. We have investigated the relation of IOP with CCT in normal, healthy pre-presbyopic persons.
\end{abstract}

\section{METHODS}

A total population of 698 normal patients (1396 eyes), aged 4 to 40 years, were evaluated in two separate clinics, one in Houston, Texas, USA and the second in Oakville, Ontario, Canada. IOP was measured using a noncontact tonometry (NCT 20 Topcon). In Houston, CCT was determined by using the Pentacam (Occulus Pentacam - Belinea) and an optical pachymetry that utilized optical low-coherence reflectometry (OLCR) technology, and in Oakville, a Hagg-Streit slit lamp-mounted pachymeter was used.

\section{RESULTS}

Of the total number of eyes tested, 1226 eyes had IOP of 21 millimetres of mercury $(\mathrm{mm} \mathrm{Hg})$ or lower and 134 eyes had IOP greater than $21 \mathrm{~mm} \mathrm{Hg}$. For the normal IOP group ( $n=1226$ eyes), the overall IOP mean was 15.63 +/- $2.87 \mathrm{~mm} \mathrm{Hg}$; the overall CCT mean was 550.21 +/- 39.64 micrometres $(\mu \mathrm{m})$. In the normal IOP group, for every $10 \mu \mathrm{m}$ change in CCT, IOP changed a statistically significant amount of $2.49 \mathrm{~mm} \mathrm{Hg}(p<0.05$ to $<0.001)$, except for the $10 \mathrm{~nm}$ CCT bins above and below the $550 \mu \mathrm{m}$ mean.

\section{CONCLUSIONS}

Although many investigators have described a positive correlation between IOP and CCT, this relationship has not been demonstrated in normal, healthy pre-presbyopic persons. There is a significant change of IOP with CCT (2.49 mm Hg IOP change per $100 \mu \mathrm{m}$ of CCT). These normative data allow primary eye care clinicians to accurately determine normal and abnormal IOP and refine the index of suspicion for identifying patients who need to be worked up for glaucoma.

\section{KEY WORDS:}

central cornea thickness, intraocular pressure, noncontact tonometry, glaucoma 
Sommaire

BUT

Les facteurs associés à un risque accru de glaucome comprennent la pression intraoculaire (PIO), l'épaisseur cornéenne centrale (ECC), le rapport cup/disc vertical, le relevé de champ visuel, l'âge et le diabète sucré. On a étudié la relation entre la PIO et l'ECC chez des personnes normales et en bonne santé ayant une prépresbytie.

\section{MÉTHODES}

On a évalué un nombre total de 698 patients normaux (1396 yeux), âgés de 4 à 40 ans, dans deux cliniques distinctes : l'une à Houston, au Texas, aux États Unis, l'autre à Oakville, en Ontario, au Canada. On a mesuré la PIO à l'aide d'un tonomètre sans contact (NCT 20 de Topcon). À Houston, on a déterminé l'ECC au moyen d'une Pentacam (Pentacam d'Occulus - Belinea) et d'un pachymètre optique ayant recours à la technologie de la réflectométrie à faible cohérence optique (RFCO); à Oakville, on a utilisé un pachymètre avec lampe à fente de Hagg Streit.

\section{RÉSULTATS}

Parmi tous les yeux examinés, 1226 yeux présentaient une PIO de 21 millimètres de mercure $(\mathrm{mm} \mathrm{Hg})$ ou moins, et 134 yeux avaient une PIO supérieure à $21 \mathrm{~mm} \mathrm{Hg}$. Pour le groupe ayant une PIO normale ( $n=1226$ yeux), la moyenne de la PIO globale était de 15,63 mm Hg, $\pm 2,87$ $\mathrm{mm} \mathrm{Hg}$. La moyenne de l'ECC globale était de 550,21 micromètres $(\mu \mathrm{m}), \pm 39,64 \times \mathrm{m}$. Dans le groupe ayant une PIO normale, pour chaque variation de 10 nanomètres (nm) de l'ECC, la PIO changeait d'une quantité statistiquement significative, à savoir $0,249 \mu \mathrm{m}(p<0,05$ à $<0,001)$, sauf pour les compartiments de l'ECC de $10 \mathrm{~nm}$ inférieurs ou supérieurs à la moyenne de $550 \mu \mathrm{m}$.

\section{CONCLUSION}

De nombreux chercheurs ont décrit une corrélation positive entre la PIO et l'ECC, mais cette relation n'a pas été démontrée chez des personnes normales en bonne santé ayant une prépresbytie. Il existe une variation significative de la PIO en fonction de l'ECC (variation de la PIO de 2,49 mm Hg par $100 \mu \mathrm{m}$ d'ECC). Ces données normatives permettent aux techniciens en soins oculovisuels primaires de déterminer une PIO normale et anormale et d'affiner l'indice de suspicion servant à identifier les patients devant faire l'objet d'analyses concernant un glaucome. être personnalisées. Une seule étude, comme AREDS 2, bien que très importante, ne peut déterminer à elle-seule le comportement clinique des professionnels de la vue. L'importance du suivi régulier du patient doit également être comprise par tous.

$\mathrm{M}$ any investigators have described a positive correlation between IOP and CCT. ${ }^{1-23}$ Others have provided a CCT-correction factor for IOP; taking all of the data of these studies together, the average correction factor for IOP is $2.6 \mathrm{~mm} \mathrm{Hg}$ per $100 \times \mathrm{m}$ CCT with a range of 0.0 to $6.3 \mathrm{~mm} \mathrm{Hg.,9,24-34}$ See Table 1 .

Although the relationship between IOP and CCT has been studied in various populations, a wide range of IOP cases have not been investigated in large numbers of normal healthy prepresbyopic subjects in North America (USA and Canada) using standard clinical screening measures of IOP (non-contact tonometry or NCT). What is not well delineated is an answer to a general research question: Can the index of suspicion for identifying primary care patients who require a workup for glaucoma be refined by determining a CCT-corrected IOP measured by NCT? 
Table 1. Studies Quantifying the Relationship between Intraocular Pressure (IOP) and Central Corneal

Thickness (CCT)

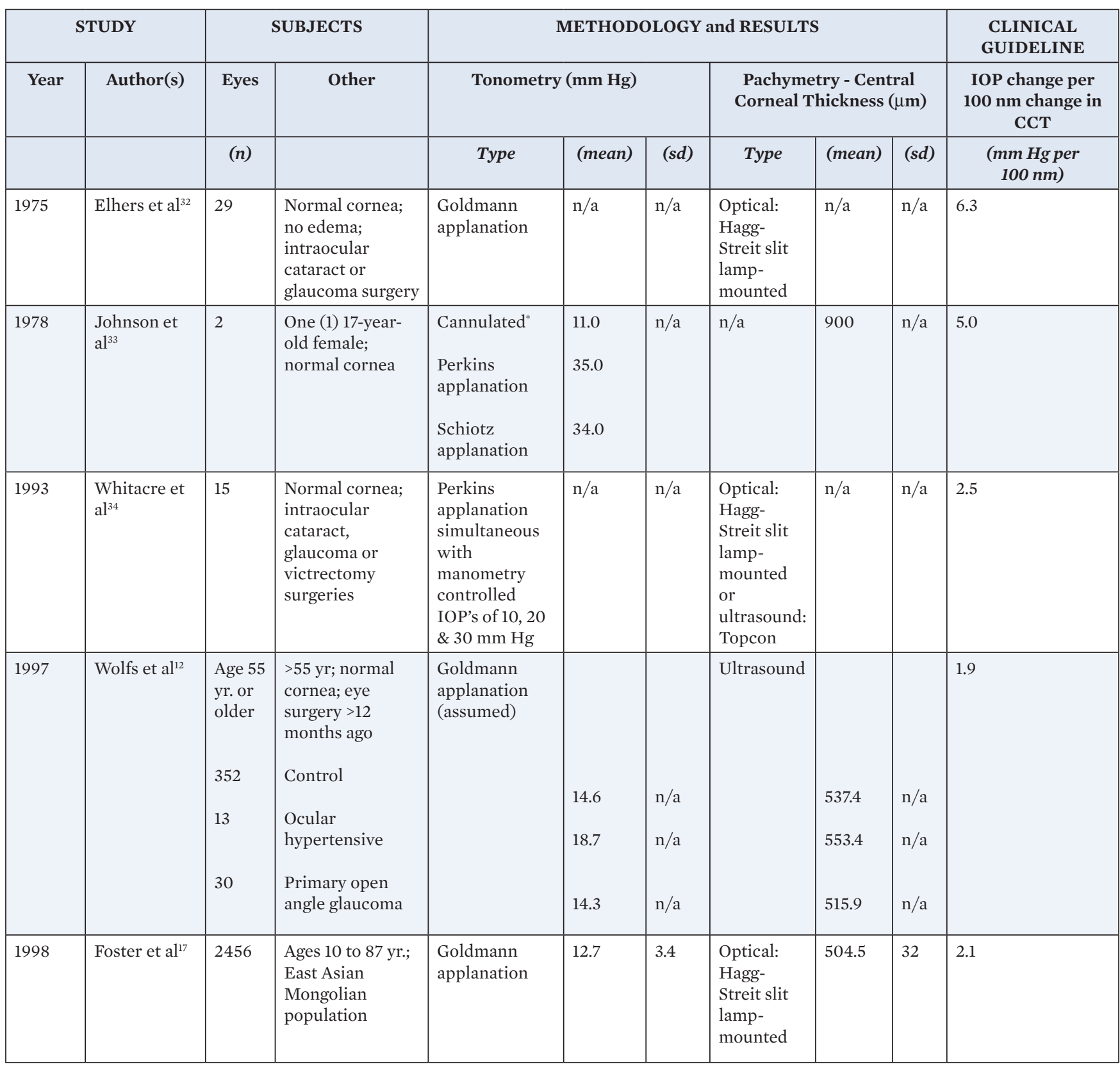




\begin{tabular}{|c|c|c|c|c|c|c|c|c|c|c|}
\hline \multicolumn{11}{|c|}{ Table 1 continued } \\
\hline \multicolumn{11}{|c|}{ Studies Quantifying the Relationship Between Intraocular Pressure and Central Corneal Thickness } \\
\hline \multicolumn{2}{|c|}{ STUDY } & \multicolumn{2}{|c|}{ SUBJECTS } & \multicolumn{6}{|c|}{ METHODOLOGY and RESULTS } & \multirow{3}{*}{$\begin{array}{c}\text { CLINICAL } \\
\text { GUIDELINE } \\
\begin{array}{l}\text { IOP change } \\
\text { per } 100 \mathrm{~nm} \\
\text { change in } \\
\text { CCT }\end{array} \\
\begin{array}{c}(\mathrm{mm} \mathrm{Hg} \text { per } \\
100 \mathrm{~nm})\end{array}\end{array}$} \\
\hline \multirow[t]{2}{*}{ Year } & \multirow[t]{2}{*}{ Author(s) } & \multirow{2}{*}{$\begin{array}{l}\text { Eyes } \\
\text { (n) }\end{array}$} & \multirow[t]{2}{*}{ Other } & \multicolumn{3}{|c|}{ Tonometry (mm Hg) } & \multicolumn{3}{|c|}{$\begin{array}{c}\text { Pachymetry - Central } \\
\text { Corneal Thickness }(\mu \mathrm{m})\end{array}$} & \\
\hline & & & & Type & (mean) & $(s d)$ & Type & (mean) & $(s d)$ & \\
\hline 2001 & $\begin{array}{l}\text { Feltgen et } \\
\mathrm{al}^{35}\end{array}$ & 73 & $\begin{array}{l}\text { Intraocular } \\
\text { glaucoma or } \\
\text { retinal surgery; } \\
\text { ages } 13 \text { to } 88 \\
\text { yrs., mean } \\
=40.7\end{array}$ & $\begin{array}{l}\text { Intracameral cannula } \\
\text { Perkins applanation } \\
\text { Tono-Pen }\end{array}$ & $\begin{array}{l}19.5 \\
17.5 \\
18.7\end{array}$ & $\begin{array}{l}6.5 \\
6.5 \\
7.2\end{array}$ & Ultrasound & 580 & 54 & 0.0 \\
\hline 2001 & Singh et $\mathrm{al}^{36}$ & $\begin{array}{l}41 \\
10 \\
13\end{array}$ & $\begin{array}{l}\text { Control } \\
\text { Ocular } \\
\text { hypertensive } \\
\text { Normal } \\
\text { pressure } \\
\text { glaucoma } \\
\text { Primary open } \\
\text { angle glaucoma }\end{array}$ & $\begin{array}{l}\text { Goldmann } \\
\text { applanation/ } \\
\text { pneumotonometry }\end{array}$ & $\begin{array}{l}15.7 / 14.1 \\
\\
24.6 / \\
20.5 \\
\\
15.7 / 14.9 \\
27.5 / \\
22.8\end{array}$ & $\begin{array}{l}1.8 / 2.3 \\
2.1 / 2.9 \\
2.9 / 2.7 \\
5.1 / 5.0\end{array}$ & Ultrasound & $\begin{array}{r}554 \\
570 \\
538 \\
547 \\
5 \\
5\end{array}$ & 32 & 2.0 \\
\hline 2002 & Bhan et $\mathrm{al}^{37}$ & 181 & Normal cornea & $\begin{array}{l}\text { Tono-pen } \\
\text { Goldmann applanation } \\
\text { Ocular Blood } \\
\text { Flow (OBF) } \\
\text { pneumotonometry }\end{array}$ & $\begin{array}{l}14.7 \\
14.4 \\
16.4\end{array}$ & $\begin{array}{l}5.0 \\
4.9 \\
6.4\end{array}$ & Ultrasound & 551 & 49 & $\begin{array}{l}1.0 \\
2.3 \\
2.8\end{array}$ \\
\hline 2002 & $\begin{array}{l}\text { Doughty et } \\
\text { al }^{38}\end{array}$ & $\begin{array}{l}104 \\
75 \\
91\end{array}$ & $\begin{array}{l}\text { Normal cornea; } \\
\text { European; ages } \\
5 \text { to } 15 \text { yr. } \\
\text { Normal cornea; } \\
\text { European; ages } \\
32 \text { to } 60 \text { yr. } \\
\text { Normal cornea; } \\
\text { European; ages } \\
61 \text { to } 82 \text { yr. }\end{array}$ & $\begin{array}{l}\text { Noncontact } \\
\text { Perkins } \\
\text { applanation } \\
\text { Perkins applanation }\end{array}$ & 13.0 & 2.9 & $\begin{array}{l}\text { Ultrasound } \\
\& \text { specular } \\
\text { microscopy }\end{array}$ & 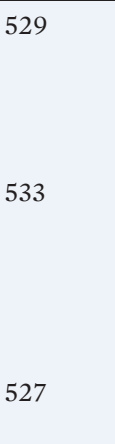 & 34 & $\begin{array}{l}2.5 \\
1.9\end{array}$ \\
\hline
\end{tabular}




\begin{tabular}{|c|c|c|c|c|c|c|c|c|c|c|}
\hline \multicolumn{11}{|c|}{ Table 1 continued } \\
\hline \multicolumn{11}{|c|}{ Studies Quantifying the Relationship Between Intraocular Pressure and Central Corneal Thickness } \\
\hline \multicolumn{2}{|c|}{ STUDY } & \multicolumn{2}{|c|}{ SUBJECTS } & \multicolumn{6}{|c|}{ METHODOLOGY and RESULTS } & \multirow{3}{*}{$\begin{array}{c}\text { CLINICAL } \\
\text { GUIDELINE } \\
\begin{array}{c}\text { IOP change per } 100 \\
\text { nm change in CCT }\end{array} \\
\begin{array}{c}(\mathrm{mm} \mathrm{Hg} \text { per } \\
100 \mathrm{~nm})\end{array}\end{array}$} \\
\hline \multirow[t]{2}{*}{ Year } & \multirow[t]{2}{*}{ Author(s) } & \multirow{2}{*}{$\begin{array}{c}\text { Eyes } \\
(n)\end{array}$} & \multirow[t]{2}{*}{ Other } & \multicolumn{3}{|c|}{ Tonometry (mm Hg) } & \multicolumn{3}{|c|}{$\begin{array}{c}\text { Pachymetry - Central } \\
\text { Corneal Thickness }(\mu \mathrm{m})\end{array}$} & \\
\hline & & & & Type & (mean) & $(s d)$ & Type & (mean) & (sd) & \\
\hline 2006 & $\begin{array}{l}\text { Kohlhaas } \\
\text { et } \mathrm{al}^{39}\end{array}$ & 125 & $\begin{array}{l}\text { Normal cornea; } \\
\text { ages } 18 \text { to } 91 \mathrm{yr} \text {, } \\
\text { mean = } 72.9+ \\
13.2 ; \text { cataract } \\
\text { surgery; } \\
\text { masked, } \\
\text { prospective } \\
\text { clinical trial }\end{array}$ & $\begin{array}{l}\text { Perkins } \\
\text { applanation } \\
\text { simultaneous } \\
\text { with } \\
\text { manometry } \\
\text { controlled IOPs } \\
\text { of } 20,35 \text { and } 50 \\
\mathrm{~mm} \mathrm{Hg}\end{array}$ & $\mathrm{n} / \mathrm{a}$ & $\mathrm{n} / \mathrm{a}$ & Ultrasound & 569 & 44 & 4.0 \\
\hline 2011 & $\begin{array}{l}\text { Heidary et } \\
\mathrm{al}^{40}\end{array}$ & 180 & $\begin{array}{l}\text { Normal cornea; } \\
\text { ages } 8 \text { to } 16 \text { yr.; } \\
\text { Malay } \\
\text { population }\end{array}$ & Noncontact & 15.7 & 3.1 & $\begin{array}{l}\text { Specular } \\
\text { microscope }\end{array}$ & 530.9 & 31 & 3.5 \\
\hline 2012 & $\begin{array}{l}\text { Sakalar et } \\
\mathrm{al}^{41}\end{array}$ & 30,320 & $\begin{array}{l}\text { Normal cornea; } \\
\text { ages } 8 \text { to } 16 \text { yr.; } \\
\text { Turkish } \\
\text { population }\end{array}$ & Noncontact & 14.2 & 2.9 & Ultrasound & 558.3 & 34 & 0.2 \\
\hline 2012 & Fern et $\mathrm{al}^{42}$ & 670 & $\begin{array}{l}\text { Normal cornea; } \\
\text { ages } 17 \text { to } 22 \text { yr.; } \\
\text { The COMET } \\
\text { Study Group }\end{array}$ & $\begin{array}{l}\text { Goldmann } \\
\text { applanation }\end{array}$ & 15.1 & $\begin{array}{l}0.1 \\
\text { SE }\end{array}$ & Ultrasound & 562.4 & $\begin{array}{l}1.8 \\
\mathrm{SE}\end{array}$ & 2.0 \\
\hline & & & & & & & & & & Average $=2.6$ \\
\hline
\end{tabular}

*Cannulated tonometry means cannulation of anterior chamber of eye and manometric determination of intraocular pressure (IOP).

OHT - ocular hypertensive subject

POAG - primary open-angle glaucoma

SE- standard error

This question is important because in general, the most commonly used screening measure of IOP is the NCT. In a population-based prevalence survey of more than 5000 individuals aged 40 years and over, participants who had a screening IOP greater than $30 \mathrm{~mm} \mathrm{Hg}$ were over 38 times more likely to have glaucoma (as defined in the study) compared with individuals with an IOP below $15 \mathrm{~mm} \mathrm{Hg} .{ }^{35}$ In the Blue Mountains Eye Study, the odds of developing glaucoma were four to seven times higher when the screening IOP was greater than $21 \mathrm{~mm} \mathrm{Hg}$ than in those with lower IOP. ${ }^{36}$ Further, the chances of developing glaucoma is two to eight times higher in patients with IOP asymmetry between eyes greater than $3 \mathrm{~mm} \mathrm{Hg}$ than in patients with smaller or no intraocular pressure asymmetry. ${ }^{37}$ Thus, although the level of IOP is directly related to the probability of glaucomatous visual field loss, it is not currently known how the use of the screening NCT relates to CCT.

Further, research indicates that CCT-corrected IOP formula seems to oversimplify the relationship of a "true" IOP based on pachymetry measurement. Currently, CCT results are commonly classified as thin, average, or thick. ${ }^{38}$ The Ocular Hypertensive Treatment Study (OHTS) showed that CCT was a significant predictor of which patients with ocular hypertension are at higher risk for converting to glaucoma (eyes with CCT of $555 \mu \mathrm{m}$ or less had a threefold greater risk of developing glaucoma compared with eyes that had CCT of more than $588 \mu \mathrm{m}) .^{18}$ 
In a study using CCT-corrected IOP, the OHTS prediction model did not perform better than the original model (without the CCT-corrected IOP), and analysis showed that CCT continued to be a statistically significant predictor in the multivariate model (Table 2) ${ }^{39} \mathrm{CCT}$ is a predictor of ocular hypertension converting to glaucoma, which is not fully explained by a CCT-corrected IOP adjustment. CCT is not to be considered a true independent risk factor for glaucoma. ${ }^{40}$

The validity of CCT-corrected IOP is based on the accuracy and precision of these measurements. Accuracy is the degree of closeness of a measured quantity to its true value. Precision (reproducibility or repeatability), which is closely related to accuracy, is the degree to which repeated measurements show similar results. ${ }^{41}$

The cornea, which is the most anterior tissue of the eye, is a transparent curved tissue, which vaults over the iris, pupil, and anterior chamber. ${ }^{42}$ The cornea refracts light with the crystalline lens to focus images on the retina; the cornea accounts for approximately two-thirds of the eye's

Table 2. Central Corneal Thickness (CCT) Groups with Mean IOP and Statistical Analysis for the Normal IOP Group $(7-20 \mathrm{~mm} \mathrm{Hg})$

\begin{tabular}{|c|c|c|c|c|c|c|c|c|c|}
\hline Row & $\begin{array}{l}\text { Number } \\
\text { of Eyes }\end{array}$ & $\begin{array}{c}\text { Range } \\
\text { CCT }(\mu \mathrm{m})\end{array}$ & $\begin{array}{c}\text { CCT } \\
\text { Group }\end{array}$ & $\begin{array}{c}\text { Mean IOP } \\
(\mathrm{mm} \mathrm{Hg})\end{array}$ & $S D$ & $\begin{array}{c}\text { Standard } \\
\text { Error of the } \\
\text { Mean }\end{array}$ & t-value & $\begin{array}{c}\text { Significance } \\
\text { (p) }\end{array}$ & $\begin{array}{l}\text { Degrees of } \\
\text { Freedom } \\
\quad(d f)\end{array}$ \\
\hline $1^{\mathrm{c}}$ & 9 & $359-454$ & $\mathrm{n} / \mathrm{a}$ & $\mathrm{n} / \mathrm{a}$ & $\mathrm{n} / \mathrm{a}$ & $\mathrm{n} / \mathrm{a}$ & $\mathrm{n} / \mathrm{a}$ & $\mathrm{n} / \mathrm{a}$ & $\mathrm{n} / \mathrm{a}$ \\
\hline $2^{\mathrm{b}}$ & 8 & $455-464$ & 460 & 12.75 & 3.01 & 1.06 & 2.56 & $<0.01$ & 113 \\
\hline $3^{b}$ & 8 & $465-474$ & 470 & 13.13 & 3.72 & 1.32 & 1.81 & $<0.05$ & 113 \\
\hline 4 & 23 & $475-484$ & 480 & 14.15 & 2.17 & 0.45 & 2.71 & $<0.01$ & 128 \\
\hline 5 & 34 & $485-494$ & 490 & 12.68 & 2.73 & 0.47 & 5.41 & $<0.001$ & 139 \\
\hline 6 & 62 & $495-504$ & 500 & 14.77 & 2.77 & 0.35 & 1.81 & $<0.05$ & 167 \\
\hline 7 & 62 & $505-514$ & 510 & 14.44 & 2.77 & 0.35 & 2.57 & $<0.02$ & 167 \\
\hline 8 & 116 & $515-524$ & 520 & 14.42 & 2.24 & 0.21 & 3.48 & $<0.001$ & 221 \\
\hline 9 & 114 & $525-534$ & 530 & 14.84 & 3.13 & 0.29 & 1.84 & $<0.05$ & 219 \\
\hline 10 & 112 & $535-544$ & 540 & 15.43 & 2.94 & 0.28 & 0.32 & $>0.5$ & 217 \\
\hline $11^{\mathrm{a}}$ & 107 & $545-554$ & 550 & 15.55 & 2.58 & 0.25 & 0.00 & $>0.5$ & 212 \\
\hline 12 & 136 & $555-564$ & 560 & 16.07 & 2.69 & 0.23 & -1.53 & $>0.05$ & 241 \\
\hline 13 & 109 & $565-574$ & 570 & 16.23 & 2.38 & 0.23 & -2.01 & $<0.05$ & 214 \\
\hline 14 & 103 & $575-584$ & 580 & 16.85 & 2.48 & 0.24 & -3.72 & $<0.001$ & 208 \\
\hline 15 & 77 & $585-594$ & 590 & 17.04 & 2.46 & 0.28 & -3.97 & $<0.001$ & 182 \\
\hline 16 & 45 & $595-604$ & 600 & 16.43 & 2.71 & 0.40 & -1.85 & $<0.05$ & 150 \\
\hline 17 & 29 & $605-614$ & 610 & 16.83 & 2.88 & 0.53 & -2.17 & $<0.05$ & 134 \\
\hline 18 & 26 & $615-624$ & 620 & 17.63 & 2.26 & 0.44 & -4.09 & $<0.001$ & 131 \\
\hline $19^{\mathrm{b}}$ & 17 & $625-634$ & 630 & 18.00 & 2.32 & 0.56 & -3.98 & $<0.001$ & 122 \\
\hline $20^{\mathrm{b}}$ & 13 & $635-644$ & 640 & 18.36 & 1.84 & 0.51 & -4.95 & $<0.001$ & 118 \\
\hline $21^{\mathrm{b}}$ & 7 & $645-654$ & 650 & 17.21 & 2.38 & 0.90 & -1.78 & $<0.05$ & 112 \\
\hline $22^{c}$ & 9 & $655-701$ & $\mathrm{n} / \mathrm{a}$ & $\mathrm{n} / \mathrm{a}$ & $\mathrm{n} / \mathrm{a}$ & $\mathrm{n} / \mathrm{a}$ & $\mathrm{n} / \mathrm{a}$ & $\mathrm{n} / \mathrm{a}$ & $\mathrm{n} / \mathrm{a}$ \\
\hline
\end{tabular}

${ }^{a}$ Mean CCT group

${ }^{\mathrm{b}} \mathrm{CCT}$ groups with less than 20 eyes

${ }^{c} \mathrm{CCT}$ groups with less than 7 or no eyes 
Figure 1. In this diagram of intraocular pressure distribution there is a visible skew toward higher pressures (exaggerated slightly compared to the actual distribution). The average pressure among those with glaucomatous visual field loss is in the low 20s, even though glaucoma is not present in most individuals with similar pressures. And, although it is not common, some individuals with pressures in the upper teens have glaucomatous visual field loss.

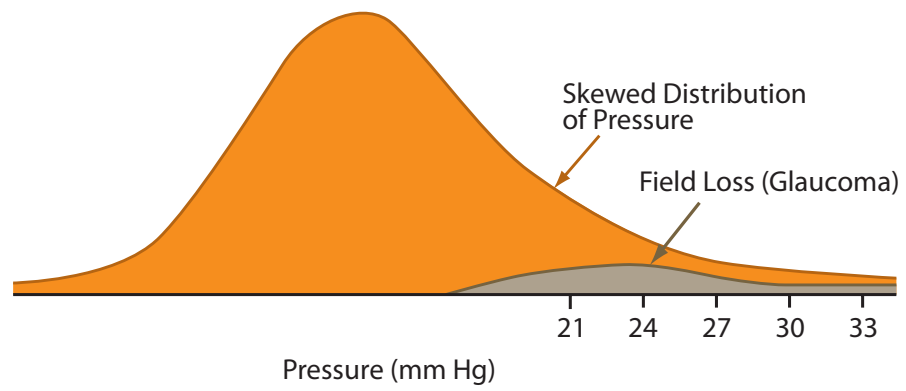

No Field Loss

Field Loss

total optical power. ${ }^{43}$ The adult CCT of approximately $540 \mu \mathrm{m}$ is reached by the age of 3 years ${ }^{1,2}$ and remains stable throughout life. ${ }^{3,44}$ The accuracy and precision of CCT measurement vary slightly with different instruments. ${ }^{45-52}$

IOP is the fluid pressure in the eye measured in millimetres of mercury. IOP is mainly determined by the coupling of the production of aqueous humour from the eye's ciliary body and its drainage through the anterior chamber angle, specifically the trabecular meshwork and Schlemm's canal. The normal range for IOP is 10 to $21 \mathrm{~mm} \mathrm{Hg}$, with a mean of $15.5 \mathrm{~mm} \mathrm{Hg.}{ }^{53}$ Clinically, IOP is measured with a Goldmann applanation tonometer or, more commonly, its derived successor, the noncontact (air-puff) tonometer (NCT). Corneal thickness and rigidity influence IOP, according to the Imbert-Fick law. This law states that the force to applanate the anterior corneal surface is equal to the true IOP times the applanated area at the posterior corneal surface, assuming the cornea is $520 \mu \mathrm{m}$ thick. ${ }^{54,55}$ Corneal indentation produced by a fixed force depends on many factors, including CTT, elasticity, and viscoelasticity, as well as other structural and physiological properties of the cornea. IOP is maintained throughout life. It is similar between the genders, and diurnal and some seasonal variations may exist. ${ }^{56}$ The IOP distribution in the general population is not a normal Gaussian distribution but is skewed toward higher pressures, where an associated increase in visual field loss is often present (Figure 1). ${ }^{57}$ IOP measurement has been shown to be accurate and precise with a number of instruments, including NCT, which may be used as a screening device for IOP measurement. ${ }^{58-64}$

The challenge is investigating IOP with the use of screening devices available in a primary eye care setting (NCT) and determining the relationship between IOP and CCT in normal healthy pre-presbyopic persons.

Taken together, answers to our specific research question-is there a difference in intraocular pressure, as measured with a screening NCT, with varying central corneal thickness in a normal healthy pre-presbyopic population?-and our research objective-to provide data for young normal patients, gathered using screening IOP measuring devices available in a primary eye care setting (NCT), which delineate the relationship between IOP and CCT-will allow routine clinical measures to refine the index of suspicion for identifying primary care patients who require a workup for glaucoma.

\section{METHODS}

In the Houston-Oakville study, a total of 698 normal healthy pre-presbyopic patients (1396 eyes) were evaluated in two separate clinics located in Houston, Texas (USA) and Oakville, 
Ontario (Canada). After written informed consent was obtained, data collected included each patient's age, race (by self-report), gender, date of birth, IOP, and CCT.

In Houston, consecutive patients were included from the date of study onset. In Oakville, patients were selected on the basis of willingness to undergo the Optos examination. Young normal subjects aged 4 to 40 years were included. Patients aged 4 years or less (due to lack of cooperation) and those over age 41 years (who were more at risk for glaucoma due to their age) were excluded. Data from a few patients were not included due to inability to procure accurate anterior segment assessment with the Pentacam. Patients with glaucoma (visual field defects, visible optic disc damage, or nerve fiber layer thinning) and those who had undergone Lasik or corneal transplant surgeries were also excluded.

\section{Intraocular Pressure}

NCT, with the Topcon CT-20 auto-NCT, was performed on all patients, at both clinics in the United States and Canada. NCT utilizes an applanation tonometer, which works on the principle of a time interval. It determines IOP by measuring the time in milliseconds from the initial generation of the puff of air to the time when the cornea is flattened exactly to the point where the timing device stops. Patients with all IOP levels were included. NCT use allowed the findings of this study to be generalized to routine clinical vision care.

\section{Central Corneal Thickness}

In Houston, the Pentacam (Occulus Pentacam - Belinea) was used for every patient to determine CCT. The Pentacam is an instrument that uses a rotating Scheimpflug camera to take multiple images of the anterior segment. The centre of the cornea is precisely measured with this rotational imaging process. Measurements take less than 2-seconds apart, and minute eye movements are captured and simultaneously corrected. Images are analyzed by a computer to generate three-dimensional images and calculate the measurements of the eye, including corneal topography, corneal thickness, AC depth, volume, angle, and pupil diameter. In Oakville, a Hagg-Streit slit-lamp mounted optical-pachymeter was used to determine corneal thickness; the Hagg-Streit optical-pachymeter utilizes OLCR (optical low-coherence reflectometry) technology.

\section{RESULTS}

From the Houston-Oakville study capture of 698 patients (1396 eyes), complete data were obtained to evaluate 1360 eyes. Of those 1360 eyes, 1226 eyes had normal IOP (range 7-21 mm $\mathrm{Hg}$ ), with 514 eyes of male subjects $(n=257$, average age $17.01+/-16.3$, range $5-40)$ and 712 eyes of female subjects ( $n=356$; average age $20.61+/-9.65$, range $4-39)$.

Of the 1360 eyes with complete data:

- Average IOP equalled $16.05+/-3.31 \mathrm{~mm} \mathrm{Hg}$

- Average CCT equalled 551.75+/- $40.26 \mu \mathrm{m}$

Of the 1226 eyes with normal IOP (range 7-21 mm Hg):

- Average IOP equalled $15.63+/-2.87 \mathrm{~mm} \mathrm{Hg}$

- Average CCT equalled 550.21+/- $39.64 \mu \mathrm{m}$

Of the 134 eyes with high IOP $(>21 \mathrm{~mm} \mathrm{Hg})$ :

- Average IOP equalled $22.48+/-3.13 \mathrm{~mm} \mathrm{Hg}$

- Average CCT equalled $583.75+/-43.49 \mu \mathrm{m}$.

For the 1360 eyes with complete data, IOP increased with increased CCT as seen in the scatter plot of Figure 2. The R-squared value is 0.158 , which indicates that about $16 \%$ of the variance in measured IOP is associated with changes in CCT and that the other $84 \%$ of the variance is attributable to other factors (race, age, idiopathic, etc.). The slope of the scatter plot in Figure 2 is the correlation coefficient R, which is 0.397; this indicates that measured IOP and CCT are mildly correlated. 
Figure 2. For our young normal pre-presbyopic population $(n=1360$ eyes) this figure shows the scatter plot of intraocular pressure (IOP) versus central corneal thickness (CCT) measurements. The slope of the scatter plot is the correlation coefficient $r$ which is 0.397; this indicates that the measured IOP and CCT are mildly correlated. The square of the correlation coefficient $\left(r^{2}=0.158\right)$ indicates the percentage of variance in IOP that can be accounted for by knowing the CCT; that is, about $16 \%$ of the variance in measured IOP is associated with changes in CCT and the other $84 \%$ of the variance is attributable to the other factors (race, age, idiopathic, etc).

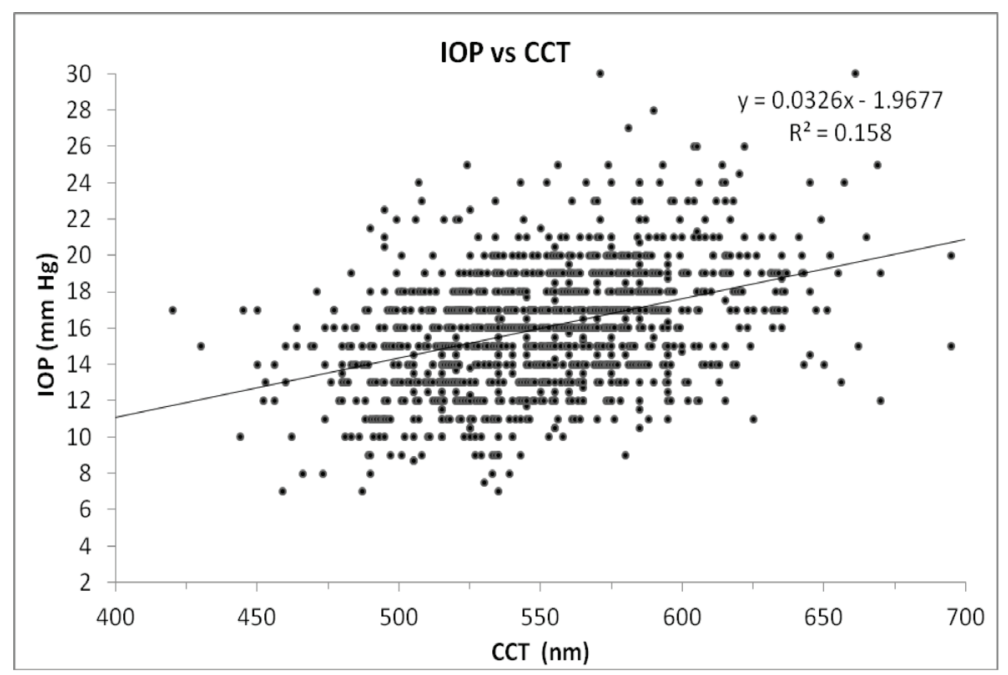

Table 3. Intraocular Pressure Increases with an Increase in Central Corneal Thickness

\begin{tabular}{|l|l|l|l|l|}
\hline CCT Group & Rows from Table 2 & CCT Range & Change in IOP & $\begin{array}{c}\text { Change in IOP per 100 } \\
\text { nm change in CCT }\end{array}$ \\
\hline 480 to 620 & 4 to 18 & 140 & 3.48 & 2.49 \\
\hline 460 to 650 & 2 to 21 & 190 & 4.46 & 2.35 \\
\hline
\end{tabular}

Figure 3. For our young normal pre-presbyopic population ( $n=1360$ eyes), 1226 eyes had normal intraocluar pressure (IOP equal or less than $21 \mathrm{~mm} \mathrm{Hg}$ ) which are included in this plot. The graph shows the average IOP $(\mathrm{mm} \mathrm{Hg})$ for each of the CCT-groups and corresponding standard deviation (SD) bars (+/-1 SD). See Table 2 for supporting data.

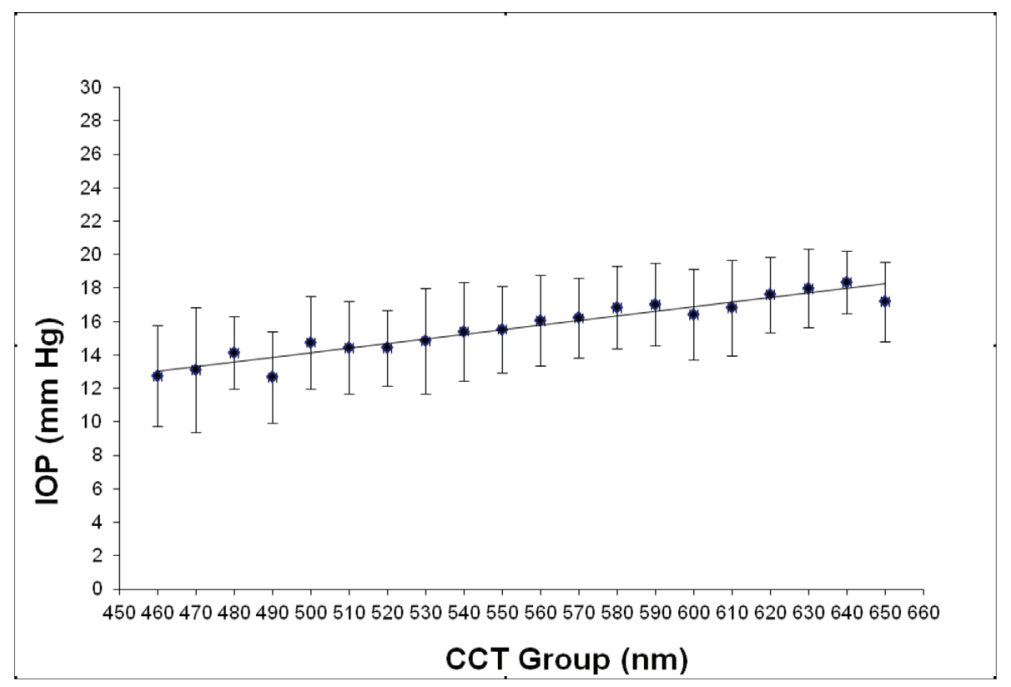


Table 4a. Young Adult Data

\begin{tabular}{|c|c|c|c|c|c|c|c|c|c|c|c|c|c|c|}
\hline \multicolumn{3}{|c|}{$\begin{array}{l}\text { Young Normal } \\
\quad(\text { IOP } \leq 21)\end{array}$} & \multicolumn{2}{|c|}{$\begin{array}{l}\text { High IOP* } \\
(\text { IOP > 21) }\end{array}$} & \multicolumn{2}{|c|}{$\begin{array}{c}\text { Asian } \\
(\text { IOP } \leq 21)\end{array}$} & \multicolumn{2}{|c|}{$\begin{array}{c}\text { Black } \\
(\text { IOP } \leq 21)\end{array}$} & \multicolumn{2}{|c|}{$\begin{array}{l}\text { Hispanic } \\
(\text { IOP } \leq 21)\end{array}$} & \multicolumn{2}{|c|}{$\begin{array}{c}\text { Other } \\
\text { (Pakistani and } \\
\text { Indian Descent) } \\
(\text { IOP } \leq 21)\end{array}$} & \multicolumn{2}{|c|}{$\begin{array}{l}\text { Caucasian } \\
(\text { IOP } \leq 21)\end{array}$} \\
\hline$N=$ & Total & 613 & Total & 81 & Total & 36 & Total & 178 & Total & 151 & Total & 82 & Total & 166 \\
\hline & Male & 257 & Male & 31 & Male & 19 & Male & 62 & Male & 71 & Male & 34 & Male & 71 \\
\hline & Female & 356 & Female & 50 & Female & 17 & Female & 116 & Female & 80 & Female & 48 & Female & 96 \\
\hline Eyes $N=$ & & 1226 & & 134 & & 72 & & 356 & & 302 & & 164 & & 332 \\
\hline & & & & & & & & & & & & & & \\
\hline & Mean & SD & Mean & SD & Mean & SD & Mean & SD & Mean & SD & Mean & SD & Mean & SD \\
\hline Age & 18.81 & 12.98 & 13.63 & 5.52 & 21.28 & 9.96 & 19.03 & 9.56 & 17.59 & 8.90 & 16.82 & 8.33 & 21.18 & 9.62 \\
\hline $\begin{array}{l}\text { Intraocular } \\
\text { pressure } \\
\text { (IOP) }\end{array}$ & 15.63 & 2.87 & 22.48 & 3.13 & 15.09 & 2.61 & 15.66 & 2.93 & 16.23 & 2.81 & 15.99 & 2.99 & 15.13 & 2.98 \\
\hline $\begin{array}{l}\text { Central } \\
\text { Corneal } \\
\text { thickness } \\
\text { (CCT) }\end{array}$ & 550.21 & 39.64 & 583.75 & 42.49 & 550.64 & 34.59 & 537.36 & 37.81 & 560.61 & 39.85 & 553.25 & 37.45 & 553.51 & 39.20 \\
\hline
\end{tabular}

*Included in the high IOP group are 1 Asian, 18 Black, 20 Hispanic, 35 Other, and

7 Caucasian who are not included in the respective Ethnicity columns.

Table 4b. $t$-Test Comparison

\begin{tabular}{|l|l|l|}
\hline \multicolumn{1}{|c|}{ Race } & \multicolumn{1}{c|}{ IOP } & \multicolumn{1}{c|}{ CCT } \\
\hline CxO & 0.02 & \\
\hline CxH & 0.001 & \\
\hline CxB & & 0.001 \\
\hline CxA & & \\
\hline CxOverAll & & \\
\hline & & \\
\hline OxH & & 0.001 \\
\hline OxB & & \\
\hline OxA & & \\
\hline & & 0.001 \\
\hline HxB & 0.02 & \\
\hline HxA & & 0.05 \\
\hline & & \\
\hline BxA & & \\
\hline
\end{tabular}

High IOP versus Normal IOP

\begin{tabular}{|c|l|}
\hline \multicolumn{1}{|c|}{ IOP } & \multicolumn{1}{|c|}{ CCT } \\
\hline & 0.01 \\
\hline & Thicker \\
\hline
\end{tabular}

High IOP thicker cornea

Figure 3 was derived by selecting those eyes $(n=1226)$ with normal IOP $(7-21 \mathrm{~mm} \mathrm{Hg})$ and then averaging the IOP for various CCT ranges or CCT groups. For example, the CCT group of $510 \mu \mathrm{m}$, IOP values of eyes $(n=62)$ with corneal thickness ranges from 505 to $514 \mu \mathrm{m}$ were averaged; for the CCT group of $520 \mu \mathrm{m}$, IOP values of eyes $(n=116)$ with corneal thickness ranges from 515 to $524 \mu \mathrm{m}$ were averaged. The mean IOP of each CCT group above or below the mean CCT group of $550 \mu \mathrm{m}$ was significantly different at the 0.05 level. Table 3 summarizes the change in IOP over a range of CCT measurements from the data in Table 2. For rows 4 to 18, which correspond to CCT groups 480 to $620 \mu \mathrm{m}$ with 20 or more eyes, the change in IOP over the $140-\mu \mathrm{m}$ CCT range was $3.48 \mathrm{~mm} \mathrm{Hg}$, hence a $2.49-\mathrm{mm} \mathrm{Hg}$ change per $100 \mu \mathrm{m}$ of CCT. For rows 2 to 21, which correspond to CCT groups 440 to $650 \mu \mathrm{m}$ with seven or more eyes, the change in IOP over the 190- $\mu \mathrm{m}$ CCT range was $4.46 \mathrm{~mm} \mathrm{Hg}$, hence a $2.35 \mathrm{~mm} \mathrm{Hg}$ change in IOP per $100 \mu \mathrm{m}$ of CCT. 
Several parameters were different in the comparison of the various groups (see Table 4).

At the 0.02 level or higher:

- Asian (15.09 +/- $2.61 \mathrm{~mm} \mathrm{Hg})$ patients had lower measured IOP than Caucasian $(15.13+/-2.98 \mathrm{~mm}$ $\mathrm{Hg})$ or Hispanic patients $(16.23+/-2.81 \mathrm{~mm} \mathrm{Hg})$.

- Caucasian $(15.13+/-2.98 \mathrm{~mm} \mathrm{Hg})$ patients had lower measured IOP than Hispanic $(16.23+/-2.81 \mathrm{~mm}$ $\mathrm{Hg})$ patients.

At the 0.01 level or higher:

- Female $(546.92+/-38.26 \mu \mathrm{m})$ patients had thinner CCT than male $(555.01+/-40.55 \mu \mathrm{m})$ patients.

- The high IOP $(>21 \mathrm{~mm} \mathrm{Hg})$ group had thicker CCT $(583.75+/-42.49 \mu \mathrm{m})$ than the normal IOP group $(555.21+/-39.64 \mu \mathrm{m})$.

At the 0.001 level or higher:

- Black patients had thinner CCT $(537.36+/-37.81 \mu \mathrm{m})$ than other groups (except Asians $p=0.05)$. The overall average of central corneal thickness was $550.21+/-39.64 \mu \mathrm{m}$.

Between-site measures were generally not significantly different. Although IOP was lower overall in Canada (14.81+/- 3.09 versus $15.85+/-2.85 \mathrm{~mm} \mathrm{Hg})$, this difference was not statistically significant when comparing Caucasian patients from Canada and the United States (14.81+/- 3.09 versus $15.13+/-2.98 \mathrm{~mm} \mathrm{Hg})$.

\section{DISCUSSION}

The clinical dilemma is that accurate assessment of IOP is important for patients who might have glaucoma (assessing the index of suspicion) and is very important for those who are being treated for glaucoma. How then, is the clinician to judge the IOP accurately in the presence of varying ranges of corneal thickness? In the Houston-Oakville study, the average:

- $\quad$ IOP equalled $15.63+/-2.87 \mathrm{~mm} \mathrm{Hg}$

- $\quad$ CCT equalled 550.21+/- $39.64 \mu \mathrm{m}$.

Each of these findings has been related to glaucoma incidence, progression, or both, but it is difficult to determine how important a given IOP finding is without knowing the CCT for a given patient. .12,18 $^{2}$

Accepting this premise makes it important to know how IOP and CCT are related. The answer to the specific research question helps identify the correction factor that might be used. The influence of CCT on measured IOP ${ }^{24,25}$ was reported as early as the 1970s; however, it is only now coming into mainstream clinical care, facilitated by new technology. Using routinely available clinical equipment (CCT measures) allows the general clinician to implement corrections and bring research into clinical care immediately.

\section{Study Limitations}

The Houston-Oakville study limitations include the method of tonometry used. Further, the study was limited to persons living at just two sites, and it may not be possible to generalize the findings to persons of similar reported ancestry living elsewhere.

The gold standard for glaucoma care is Goldmann applanation tonometry. To facilitate gathering of data, the Houston-Oakville study group elected to use a Topcon CT-20 autoNCT. NCT is a frequently used clinical test for routine IOP examination in primary eye care offices. It is possible that there will be clinical differences in IOP measurements when NCT, rather than Goldmann tonometry, is used. However, Tonnu et al.$^{65}$ found moderate agreement between NCT (Topcon CT-80) and Goldmann applanation tonometry (mean difference of 0.7 $\mathrm{mm} \mathrm{Hg}$ ), and there was no significant difference between NCT (Canon TX-10) and Goldmann applanation tonometry, in either intrasession or intersession repeatability testing (two-tail $t$-test, $p>0.075$; degree of freedom $(\mathrm{df})=119) .{ }^{66}$ Furthermore, the relation between IOP and $\mathrm{CCT}$ is the important factor, not the absolute IOP reading. 
The IOP assessment in the Houston-Oakville study was based on a single-average measure (average of two measurements taken consecutively within a 10-second time-frame) at various times throughout the day (9:00 a.m. to 7:00 p.m.). On the surface, this could be a concern, as there can be significant diurnal variations in IOP. Indeed, diurnal IOP fluctuation has been identified as an important risk factor for visual field deterioration in glaucoma. ${ }^{56} \mathrm{~A}$ single IOP measure will seldom be used to establish a diagnosis or alter treatment for any form of glaucoma. However, the result of the Houston-Oakville study compares CCT and IOP, and possible fluctuation would not influence the structural interrelations identified; and the study averages IOP measured at different times of the day. So, the IOP measured in the study is a daylight average, which moderates the extreme readings of the diurnal range of IOP measured. That said, the diurnal variation in IOP (not observed in CCT except for post-sleep corneal edema secondary to hypoxia) adds measurement noise, reduces the relationship between IOP and CCT, and lowers the R-squared value. If all measurements were taken the same time of the day, then a higher R-squared value might have been found.

\section{Corneal Thickness}

In the Houston-Oakville study, the female subjects had thinner corneas compared with the male subjects by $8.1 \mu \mathrm{m}(546.92+/-38.26 \mu \mathrm{m}$ versus $555.00+/-40.55 \mu \mathrm{m}$, respectively; $t=2.503$, $p=0.02)$. This differs from the OHTS results, which showed that the male subjects had thinner corneas by $4.7 \mu \mathrm{m}(575+/-38.6 \mu \mathrm{m}$ versus $570.3+/-39.4 \mu \mathrm{m}) .{ }^{18}$ The etiology of this difference is unclear. The OHTS investigators suggested that the cornea thins slightly with age, and the subjects of the Houston-Oakville study were substantially younger compared with the subjects of the OHTS. Perhaps the corneal thickness difference of the Houston-Oakville subjects would ultimately "cross over" so that the males would have thinner corneas, as the OHTS investigators found. In any event, the OHTS investigators did not feel that these small differences were clinically significant for glaucoma management or for accurate determination of IOP and the data from the Houston-Oakville study suggest this as well.

\section{Clinical Application}

The results of the Houston-Oakville study shed further light on how measured IOP might be "corrected" on the basis of the measures of CCT. Figure 3 was derived by averaging the IOP of 1226 eyes, with normal IOP $(7-21 \mathrm{~mm} \mathrm{Hg})$ for $10 \mu \mathrm{m}$ CCT groups between $460 \mu \mathrm{m}$ and $650 \mu \mathrm{m}$. From Table 3, the CCT groups between 480 and $620 \mu \mathrm{m}$ had 20 or more IOP measurements, and the average change of IOP per $100 \mu \mathrm{m}$ of CCT was $2.49 \mathrm{~mm} \mathrm{Hg}$. For the CCT groups with CCT between 460 and $650 \mu \mathrm{m}$, which had seven or more IOP measurements, the average change of IOP per $100 \mu \mathrm{m}$ of CCT was $2.35 \mathrm{~mm} \mathrm{Hg}$. The "correction" of $2.49 \mathrm{~mm} \mathrm{Hg}$ for every $100-\mu \mathrm{m}$ increase in corneal thickness corresponded well with previous results $(2.6 \mathrm{~mm} \mathrm{Hg}$ per $100 \mu \mathrm{m}$ of CCT; average correction from Table 1). The best "correction" factor to be used is still debated, as is whether a linear factor is even appropriate (although in Figures 2 and 3, it appears that the factor is linear for the 460-650 $\mu \mathrm{m}$ CCT range studied). Nonetheless, correction factors derived from patient samples, such as in the Houston-Oakville study, provide clinicians with a useful estimate of the effects that corneal thickness variations from a normal range may have on the IOP measurement of a given patient.

\section{CONCLUSION}

Data from the Houston-Oakville study provide new insight into the relation between CCT and IOP in young, normal persons. Evaluating and relating IOP to CCT will help improve clinical care. Identification of patients with abnormal CCT will allow the clinician to more closely estimate the accuracy of IOP readings for these patients.

\section{ACKNOWLEDGEMENTS}

Presented, in part, as a poster at the American Academy of Optometry meeting in December 2005. Thanks to Jumah Absy, Susan Che, and Bonnie Cameron, who participated in data gathering and analysis for the poster; and to Harold Bedell, Susan Che, and Heather JohnsAnderson for comments on the various versions of this manuscript. 


\section{REFERENCES}

1. Ehlers N et al. Central corneal thickness in newborns and children. Acta Ophthalmol 1976; 54(3):285-90.

2. Muir KW, Jin J, Freedman SF. Central corneal thickness and its relationship to intraocular pressure in children. Ophthalmology 2004;111(12):2220-3.

3. Doughty MJ, Zaman ML. Human corneal thickness and its impact on intraocular pressure measures: a review and meta-analysis approach. Surv Ophthalmol 2000; 44(5):367-408.

4. Wolfs RC, Klaver CC, Vingerling JR, et al. Distribution of central corneal thickness and its association with intraocular pressure: the Rotterdam study. Am J Ophthalmol 1997;123(6):767-72.

5. Herndon LW, Choudri SA, Cox T, et al. Central corneal thickness in normal, glaucomatous and ocular hypertensive eyes. Arch Ophthalmol 1997;115:1137-41.

6. Dohadwala AA, Munger R, Damji KF. Positive correlation between Tono-Pen intraocular pressure and central corneal thickness. Ophthalmology 1998;105:184954.

7. Shah S, Chatterjee A, Mathai M, et al. Relationship between corneal thickness and measure intraocular pressure in a general ophthalmology clinic. Ophthalmology 1999;106:2154-60.

8. Lleo A, Marcos A, Calatayud M, Alonso L, et al. The relationship between central corneal thickness and Goldman applanation tonometry. Clin Exp Optom 2003 86(2):104-8

9. Foster PJ, Baasanhu J, Alsbirk PH, et al. Central corneal thickness and intraocular pressure in a Mongolian population. Ophthalmology 1998;105:969-73.

10. La Rosa FA, Gross RL, Orengo-Nania S. Central corneal thickness of Caucasians and African Americans in glaucomatous and nonglaucomatous populations. Arch Ophthalmol 2001;119:23-7.

11. Hahn S, Azen S, Ying-lai M, Varma R; Los Angeles Latino Eye Study Group. Central corneal thickness in Latinos. Invest Ophthalmol Vis Sci 2003;33:1508-12.

12. Argus WA. Ocular hypertension and central corneal thickness. Ophthalmology 1995;102:1810-2.

13. Johnson M, Kass MA, Moses R, Grodzki WJ. Increased corneal thickness simulating elevated intraocular pressure. Arch Ophthalmol 1978;96:664-5.

14. Herman DC, Hodge DO, Bourne WM. Increased corneal thickness in patients with ocular hypertension. Arch Ophthalmol 2001;119:334-6.

15. Herndon LW, Choudri SA, Cox T, et al. Central corneal thickness in normal, glaucomatous and ocular hypertensive eyes. Arch Ophthalmol 1997;115:1137-41.

16. Copt RP, Thomas R, Mermoud A. Corneal thickness in ocular hypertension, primary open-angle glaucoma, and normal tension glaucoma. Arch Ophthalmol 1999;117:14-6.

17. Ventura AC, Boehnke M, Mojon DS. Central corneal thickness measurements in patients with normal tension glaucoma, primary open angle glaucoma, pseudoexfoliation glaucoma, or ocular hypertension. Br J Ophthalmol 2001;85:792-5.

18. Brandt JD, Beiser JA, Kass MA, Gordon MO. Central corneal thickness in the ocular hypertension treatment study (OHTS). Ophthalmology 2001;108:1179-88.

19. Singh RP, Goldberg I, Graham SL, et al. Central corneal thickness, tonometry, and ocular dimensions in glaucoma and ocular hypertension. J Glaucoma 2001;10:206-10.

20. Wu LL, Suzuki Y, Ideta R, Araie M. Central corneal thickness of normal tension glaucoma patients in Japan. Jpn Ophthalmol 2000;44:643-7.

21. Emara BY, Tingey DP, Probst LE, Motolko MA. Central corneal thickness in low-tension glaucoma. Can J Ophthalmol 1999;34:319-24.

22. Morad Y, Sharon E, Hefetz L, Nemet P. Corneal thickness and curvature in normal-tension glaucoma. Am J Ophthalmol 1998;125:164-8.

23. Nemesure B, Wu SY, Hennis A, Leske MC; Barbados Eye Study Group. Corneal Thickness and intraocular pressure in the Barbados Eye Studies. Arch Ophthal- mol 2003;121:240-4.

24. Ehlers N, Bramsen T, Sperling S. Applanation tonometry and central corneal thickness. Acta Ophthalmol (Copenh) 1975;53:34-43.

25. Johnson M, Kass MA, Moses R, Grodzki WJ. Increased corneal thickness simulating elevated intraocular pressure. Arch Opthalmol 1978;96:664-5.

26. Whitacre MM, Stein RA, Hassanein K. The effect of corneal thickness on applanation tonometry. Am J Ophthalmol 1993;115:592-6.

27. Feltgen N, Leifert D, Funk J. Correlation between central corneal thickness, applanation tonometry and direct intracameral IOP readings. Br J Ophthalmol 2001;85:85-7.

28. Singh RP, Goldberg I, Graham SL, et al. Central corneal thickness, tonometry, and ocular dimensions in glaucoma and ocular hypertension. J Glaucoma 2001;10:206-10.

29. Bhan A, Browning AC, Shah S, et al. Effect of corneal thickness on intraocular pressure measurements with the pneumotonometer, Goldmann applanation tonometer, and Tono-Pen. Invest Ophthalmol Vis Sci 2002;43:1389-92.

30. Doughty MJ, Laiquzzaman M, Mueller A, et al. Central corneal thickness in European (white) individuals, especially children and the elderly, and the assessment of its possible importance in clinical measures of intra-ocular pressure. Ophthalmic Physiol Opt 2002;22(6):491-504.

31. Kohlhaas M, Boehm AG, Spoerl E, et al. Effect of central corneal thickness, corneal curvature, and axial length on applanation tonometry. Arch Ophthalmol 2006;124:471-6.

32. Heidary F, Gharebaghi R, Hitam WHW, et al. Central corneal thickness and intraocular pressure in Malay children. PlosOne 2011;6(10):e25208.

33. Sakalar YB, Keklikci U, Unlu K, et al. Distribution of central corneal thickness and intraocular pressure in a large population of Turkish school children. Ophthalmic Epidemiol 2012;19:83-8.

34. Fern KD, Manny RE, Gwiazda J, et al.; The COMET Study Group. Intraocular pressure and central corneal thickness in the COMET cohort. Optom Vis Sci 2012;89(8):1225-34.

35. Tielsch JM, Katz J, Singh K, et al. A population-based evaluation of glaucoma screening: the Baltimore Eye Survey. Am J Epidemiol 1991;134:1102-10.

36. Mitchell P, Smith W, Chey T, Healey PR. Open-angle glaucoma and diabetes. The Blue Mountains Eye Study, Australia. Ophthalmology 1997;104:712-8.

37. Goldberg I. Relationship between intraocular pressure and preservation of visual field in glaucoma. Surv Ophthalmol 2003;48 Supp 1: S3-S7.

38. Park SJK, Ang GS, Nicholas S, Wells AP. The effect of thin, thick, and normal corneas on Goldmann intraocular pressure measurements and correction formulae in individual eyes. Ophthalmology 2012;119(3):443-9.

39. Brandt JD, Gordon MO, Gao F, et al.; for the Ocular Hypertension Treatment Study Group. Adjusting intraocular pressure for central corneal thickness does not improve prediction models for primary open-angle glaucoma. Ophthalmology 2012;119(3):437-42.

40. Medeiros FA, Weinreb RN. Is corneal thickness an independent risk factor for glaucoma? Ophthalmology 2012;119(3):435-6.

41. Hulley SB, Cummings SR. Planning the measurements: precision and accuracy. In Hulley SB, Cummings SR, editors. Designing clinical research. An epidemiologic approach. Baltimore, MD: Williams \& Wilkins, 1988:31-41.

42. Cassin B, Solomon S. Dictionary of eye terminology. Gainsville, FL: Triad Publishing Company, 1990:74.

43. Goldstein EB. Sensation and perception. 7th ed. Canada: Thompson Wadsworth, 2007.

44. Muir KW, Duncan L, Enyedi, LB, et al. Central corneal thickness in children: stability over time. Am J Ophthalmol 2006;141(5):955-7. 
45. Urbak SF. Ultrasound biomicroscopy III. Accuracy and agreement of measurements. Acta Ophthalmol 1999;77(3):293-7.

46. O'Donnell C, Maldonado-Codina C. Agreement and repeatability of central thickness measurements in normal corneas using ultrasound pachymetry and the OCULUS Pentacam. Cornea 2005;24(8):920-4.

47. Marsich MW, Bullimore MA. The repeatability of corneal thickness measures. Cornea 2000;19(6):792-5.

48. Wirbelauer C, Scholz C, Hoerauf H, et al. Noncontact corneal pachymetry with slit lamp-adapted optical coherence tomography. Am J Ophthalmol 2002;133(4):444-50.

49. Kim HY, Budenz DL, Lee PS, et al. Comparison of central corneal thickness using anterior segment optical coherence tomography vs ultrasound pachymetry. Am J Ophthalmol 2008;145(2):228-32

50. Touzeau O, Allouch C, Borderie V, et al. Precision and reliability of Orbscan and ultrasonic pachymetry. J Fr Ophthalmol 2001;24(9):912-21.

51. Wheeler NC, Morantes CM, Christensen RM, et al. Reliability coefficients of three corneal pachymeters. Am J Ophthalmol 1992;113(6):645-51.

52. Bron A, Chapard J, Creuzot-Garcher C, et al. Is corneal thickness measurement reliable and useful? J Fr Ophthalmol 1999;22(2):160-8.

53. The Merck manual of diagnosis and therapy. Whitehouse Station, NJ: Merck Research Laboratories, 1999:733.

54. Tanaka GH. Corneal pachymetry: a prerequisite for applanation tonometry? Arch Ophth1998;116:544-5

55. Chihara E. Assessment of true intraocular pressure: the gap between theory and practical data. Surv Ophth 2008;53:203-18.

56. Pointer JS. The diurnal variation of intraocular pressure in non-glaucomatous subjects: relevance in a clinical context. Ophthalmic Physiol Opt. 1997;17:456-
57. Shields MB. Textbook of glaucoma. 3rd ed. ?. Lippincott Williams \& Wilkins;1992:46.

58. Foster PJ, Wong JS, Wong E, et al. Accuracy of clinical estimates of intraocular pressure in Chinese eyes. Ophthalmology 2000;107(10):1816-21.

59. Boothe WA, Lee Da, Panek WC, Pettit TH. The Tono-Pen. A manometric and clinical study. Arch Ophthalmol 1988;106(9):1214-7.

60. Ogbuehi KC, Almubrad TM. Accuracy and reliability of the Keeler Pulsair EasyEye non-contact tonometer. Optom Vis Sci 2008;85(1):61-6.

61. Almubrad TM, Ogbuehi KC. The effect of repeated applanation on subsequent IOP measurements. Clin Exp Optom 2008;91(6):524-49.

62. Bafa M, Lambrinakis I, Dayan M, Birch M. Clinical comparison of the measurement of the IOP with the ocular blood flow tonometer, the Tonopen XL and the Goldmann applanation tonometer. Acta Ophthalmol 2001;79(1):15-8.

63. Kaufman C, Bachmann LM, Thiel MA. Comparison of Dynamic Contour Tonometry with Goldmann Applanation Tonometry. Invest Ophthalmol Vis Sci 2004;45(9):3118-21.

64. Aakre BM, Doughty MJ, Dalane OV, et al. Assessment of reproducibility of measures of intraocular pressure and central corneal thickness in young white adults over a 16-h time period. Ophthalmol Phys Opt 2003;23(3):271-83.

65. Tonnu PA, Ho T, Sharma K, et al. A comparison of four methods of tonometry: method agreement and interobserver variability. Br J Ophthalmol 2005;89(7):847-50.

66. Almubrad TM, Ogbuehi KC. On repeated corneal applanation with the Goldmann and two non-contact tonometers. Clin Exp Optom 2010;93(2):77-82.

\section{Optimize your investment!}

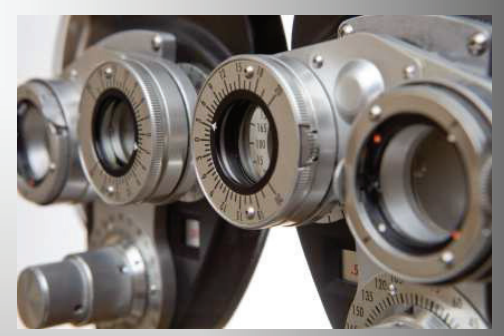

Visit us at (www.proptix.com) for the full range of instrument we cover.

Quick turn-around, warranty, $100 \%$ sati: faction, competitive rate, Free loaner.

GET EXTRA $10 \%$ OFF BY USING CODE CJO2014 